\title{
Perkembangan Model Mental Mahasiswa pada Penggunaan Bahan Ajar Kesetimbangan Kimia berbasis Inkuiri Terbimbing
}

\author{
Faizah Qurrata Aini' ${ }^{1)}$, Zonalia Fitriza' ${ }^{1)}$, Fauzana Gazali' ${ }^{1}$, Mawardi Mawardi' ${ }^{1}$, \\ Ghery Priscylio ${ }^{2)}$ \\ ${ }^{1)}$ Univeristas Negeri Padang \\ ${ }^{2)}$ Sekolah Pascasarjana Universitas Pendidikan Indonesia \\ faizah_qurrata@fmipa.unp.ac.id
}

\begin{abstract}
This research aimed to analyze students' mental models in chemical equilibrium before and after using guided inquiry-based learning material. The instrument used was a conceptual test which has been developed by Bergquist and Heikkinen. This test was taken before and after formal instruction using the learning material. Responses were obtained from 30 first-year students of Faculty of Mathematics and Natural Science of UNP which taking general chemistry course in 2017/2018 even semester using purposive sampling. Student answers to this test were analyzed descriptively. From this research, student understanding increase after using the learning material. The highest increasing is in equilibrium shifting stoichiometry concept. This gaining correlated to students' mental model development. The results of this study indicated that in general there has been a development of students" mental models before and after using this learning material. Although, not all students' model mental are appropriate to scientific concepts in chemical equilibrium.
\end{abstract}

Keywords: Mental model, Learning material, Chemical equilibrium, Chemistry instruction

(f) This is an open access article distributed under the Creative Commons 4.0 Attribution License, which permits unrestricted use, distribution, and reproduction in any medium, provided the original work is properly cited. @2018 by author and Universitas Negeri Padang.

\section{PENDAHULUAN}

Materi kesetimbangan kimia merupakan materi yang sangat penting karena materi ini merupakan salah satu konsep dasar untuk mempelajari materi kimia selanjutnya. Namun, materi ini merupakan salah satu materi kimia yang dianggap sulit dan kompleks (Chiu, Chou, \& Liu, 2002; Kousathana \& Tsaparlis, 2002; Özmen, 2007; Ollino, Aldoney, Domınguez, \& Merino, 2018) sehingga mempunyai tingkat miskonsepsi yang tinggi (Barke, Hazari, \& Yitbarek, 2009).

Kousatana dan Trapalis (2002) meng ungkapkan bahwa miskonsepsi pada materi ini disebabkan karena konsep yang tidak dihubung kan dengan pemecahan masalah perhitungan kesetimbangan. Miskonsepsi pada materi kese timbangan kimia dipengaruhi oleh pengetahuan awal mahasiswa yang menganggap semua reaksi berlangsung secara berkesudahan (Pedrosa \& Dias, 2000; Karpudewan, Treagust, Mocerino, Won, \& Chandrasegaran, 2015). Salah satu cara untuk menganalisis miskonsepsi adalah dengan melihat model mental mahasiswa (Tumay, 2014). Istilah model mental diperkenalkan untuk menjelaskan bagaimana mahasiswa membentuk suatu model pemahaman terhadap suatu proses dengan menyatukan informasi baru pada penge tahuan yang telah ada (Tumay, 2014; Johnstone, 1993; Ibrahim \& Rebello, 2013; Coll \& Taylor, 2002). Hal ini berarti bahwa miskonsepsi meru pakan model mental yang tidak sesuai dengan kebenaran ilmiah.

Model mental yang tidak benar pada materi kesetimbangan kimia berakibat pada ketidakpahaman konsep-konsep kimia selanjut nya seperti Asam Basa, Larutan Penyangga, Hidrolisis Garam, Kelarutan dan Hasil Kali Kelarutan $\left(\mathrm{K}_{\mathrm{sp}}\right)$, Sifat Koligatif Larutan, dan sebagainya (Bergquist \& Heikkinen, 1990). Oleh karena itu, dibutuhkan cara agar miskon sepsi dalam materi kesetimbangan kimia tidak terjadi sehingga didapatkan model mental yang benar pada materi ini. Salah satu cara adalah dengan menggunakan model pembelajaran inkuiri terbimbing.

Model inkuiri terbimbing dianggap seba gai salah satu pembelajaran yang paling efektif dalam pembelajaran kimia. Model ini member kan kelebihan dalam mendorong siswa berlatih menggunakan sumber belajar dan bekerja 
kelompok untuk meningkatkan pemahaman konseptual (Supasorn \& Promarak, 2015; The College Board, 2013; The College Board, 2012; Hunnicutt, Grushow, \& Whitnell, 2015; Kuhlthau, Maniotes, \& Caspari, 2007). Cullen dan Pentecost (Cullen \& Pentecost, 2011) menyatakan bahwa pembelajaran inkuiri meng arahkan mahasiswa untuk memperbaiki penge tahuan sebelumnya kemudian diarahkan mene mukan konsep menggunakan model. Model merupakan representasi dari suatu konsep yang dapat berupa gambar, tabel, diagram, kurva, praktikum, dan lain-lain (Hanson, 2013). Model ini secara tidak langsung memberikan model mental yang benar kepada mahasiswa. Pembe lajaran inkuiri terbimbing pada penelitian ini menggunakan bahan ajar yang telah dikembang kan oleh Aini, Mawardi, dan Oktavia (Aini, Mawardi, \& Oktavia, 2017) dengan melibatkan tiga level reprsentasi kimia: makroskopis, submikroskopis, dan simbolik. Keterkaitan antar ketiga level yang terdapat pada bahan ajar ini diharapkan dapat membangun model mental mahasiswa yang benar sehingga didapatkan hasil belajar yang memuaskan pada materi kesetimbangan kimia.

\section{METODE PENELITIAN}

Populasi penelitian ini adalah mahasiswa Fakultas Matematika dan Ilmu Pengetahuan Alam Universitas Negeri Padang angkatan 2017

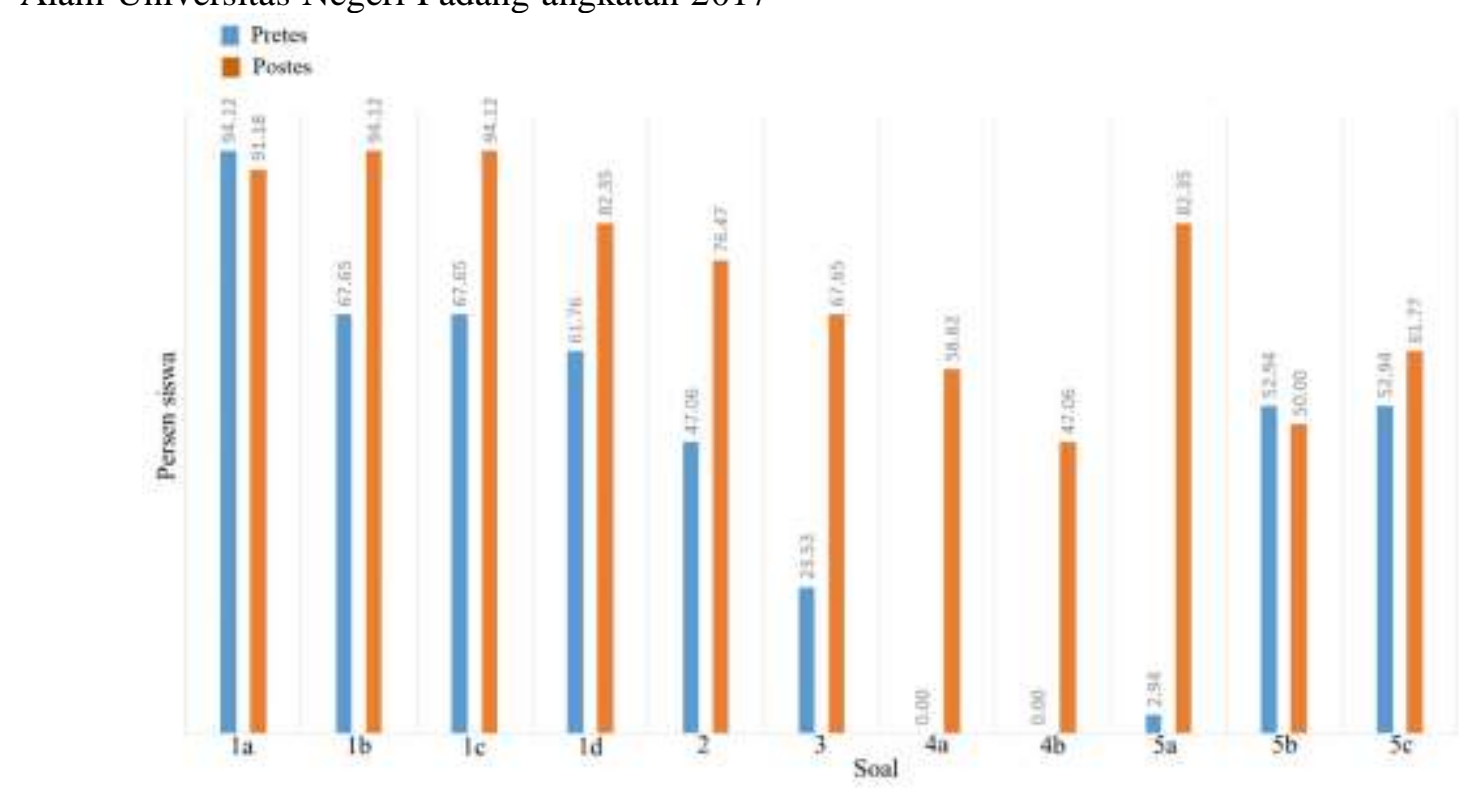

yang mengambil mata kuliah kimia umum pada semester genap tahun ajaran 2017/ 2018. Teknik pengambilan sampel berupa purposive sampling. Jumlah sampel adalah sebanyak 30 orang. Penelitian ini merupakan penelitian preeksperimen. Rancangan penelitian ini berupa the one group pretest-post-test design karena pada penelitian ini hanya terdapat satu kelas yang diberikan perlakuan berupa pembelajaran dengan menggunakan bahan ajar inkuiri terbimbing. Model mental mahasiswa dianalisis dari hasil pretes dan postes dengan menggunakan instrumen penelitian berupa tes yang telah dikembangkan oleh Bergquist dan Heikkinen (Bergquist \& Heikkinen, 1990). Tes ini merupakan tes konseptual untuk menguji pemahaman konsep mahasiswa terhadap keadaan sistem pada saat setimbang dan perubahan yang terjadi saat kesetimbangan bergeser karena diberikan perlakuan. Model mental sebelum dan setelah menggunakan bahan ajar berbasis inkuiri terbimbing dianlisis secara deskriptif dengan melihat jawaban mahasiswa pada aspek makroskopis, sub-mikroskopis, dan simbolik.

\section{HASIL DAN PEMBAHASAN}

Soal yang digunakan pada tes ini menggunakan pertanyaan yang menuntut pemahaman konsep mahasiswa terhadap konsep-konsep kesetimbangan kimia.

Gambar 1. Grafik Jawaban Mahasiswa pada Tes Konseptual Sebelum dan Sesudah Menggunakan Bahan Ajar Berbasis Inkuiri Terbimbing 
Konsep kesetimbangan kimia yang menjadi fokus dalam penelitian ini adalah konsep mengenai stoikiometri reaksi kesetimbangan meliputi keadaan sistem sebelum dan setelah mencapai kesetimbangan dan keadaan setelah system kesetimbangan diberi gangguan kemudian mencapai keadaan setimbang yang baru. Jawaban mahasiswa terhadap pertanyaan dalam tes tersebut sebelum dan setelah mempelajari materi kesetimbangan dengan menggunakan bahan ajar berbasis inkuiri terbimbing ini dapat dilihat pada Gambar 1.

Pada Gambar 1 terlihat bahwa secara umum terjadi peningkatan jumlah mahasiswa yang menjawab benar pertanyaan pada tes. Peningkatan ini juga berhubungan dengan berkembangnya model mental mahasiswa yang dilihat dari gambaran sub-mikroskopis yang dibuat oleh siswa mengenai reaksi kesetimbangan $\mathrm{H}_{2}(g)+\mathrm{I}_{2}(g) \rightleftharpoons 2 \mathrm{HI}(g)$ pada awal reaksi, saat kesetimbangan tercapai, dan saat kesetimbangan baru terbentuk setelah adanya penambahan jumlah $\mathrm{I}_{2}$. Peningkatan yang sangat besar terlihat pada soal $4 \mathrm{a}, 4 \mathrm{~b}$, dan 5a. Soal ini menguji pemahaman mahasiswa mengenai stoikiometri reaksi kesetimbangan $\mathrm{H}_{2}(g)+\mathrm{I}_{2}(g) \rightleftharpoons 2 \mathrm{HI}(g)$ setelah dimasukkan sejumlah $\mathrm{I}_{2}$ ke dalam sistem tersebut. Hal ini membuktikan bahwa bahan ajar ini dapat meningkatkan pemahaman mahasiswa mengenai

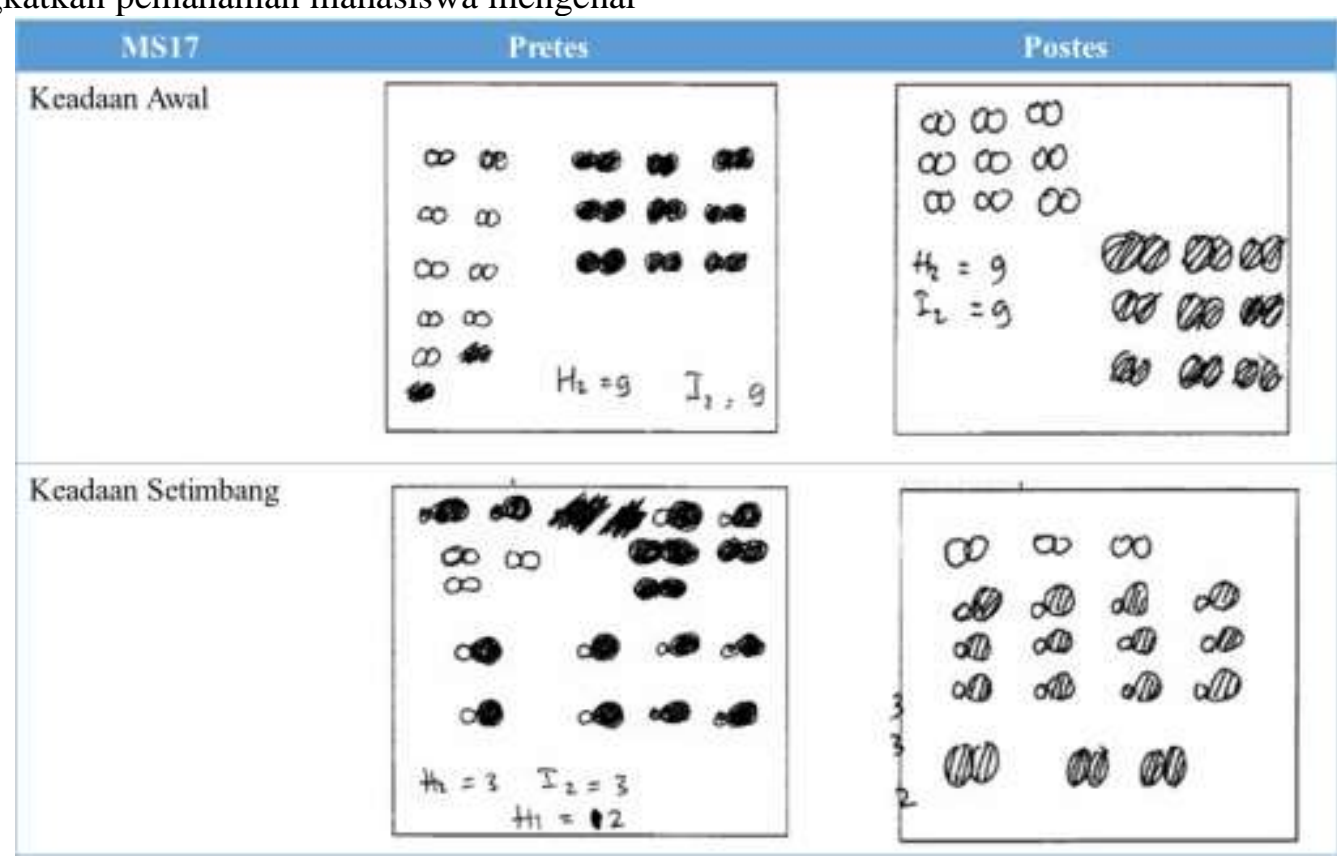

Gambar 2. Representasi Sub-Mikroskopis MS17 pada Keadaan Awal dan Setimbang pada Pretes dan Postes stoikiometri pergeseran kesetimbangan dikarenakan siswa dibimbing untuk menentukan jumlah zat saat terbentuk kesetimbangan baru dengan melibatkan ketiga aspek multiple representasi. Pada bahan ajar ini, konsep ini disajikan dengan adanya praktikum yang dilakukan mahasiswa. Pada saat praktikum, mahasiswa mengamati fenomena perubahan warna akibat penambahan atau pengurangan salah satu zat yang terlibat dalam reaksi kesetimbangan. Selanjutnya, mahasiswa menghu bungkan fenomena makroskopis ini dengan aspek sub-mikroskopis dan simbolik yang diberikan pada bahan ajar. Mahasiswa dibim bing dengan pertanyaan-pertanyaan yang menuntun mereka untuk menemukan konsep stoikiometri pergeseran kesetimbangan serta pentingnya mengetahui bahwa nilai $K_{c}$ akan tetap pada suhu tetap walaupun terjadi pergeseran kesetimbangan.

Akan tetapi peningkatan jumlah maha siswa yang menjawab benar pertanyaan pada tes tidak sepenuhnya membuat model mental maha siswa berkembang sesuai dengan kebenaran ilmiah mengenai konsep kesetimbangan kimia. Contohnya adalah Mahasiswa 17 (MS17) membuatkan representasi sub-mikroskopis saat awal reaksi dengan saat kesetimbangan pada Gambar 2. 
Pada gambar 2, terlihat bahwa pada MS17 sudah benar dalam memperhitungkan jumlah zat-zat yang bereaksi secara stoikiometri baik saat sebelum maupun setelah menggunanakan bahan ajar berbasis inkuiri terbimbing ini. Namun, saat sistem kesetimbangan diberikan aksi dengan menambahkan $I_{2}$ dan kesetimba ngan baru terbentuk, MS17 memperlihatkan bahwa ia belum memahami konsep kesetimba ngan karena berdasarkan representasi submikroskopisnya pada Gambar 3, ia membuat $\mathrm{H}_{2}$ habis. Setelah menggunakan bahan ajar, terlihat bahwa ia sudah memahami konsep kesetimba ngan bahwa dalam sistem kesetimbangan setiap zat yang terlibat dalam reaksi selalu ada walaupun ia masih tidak memahami bahwa jumlah $\mathrm{I}_{2}$ saat diberikan aksi bertambah.

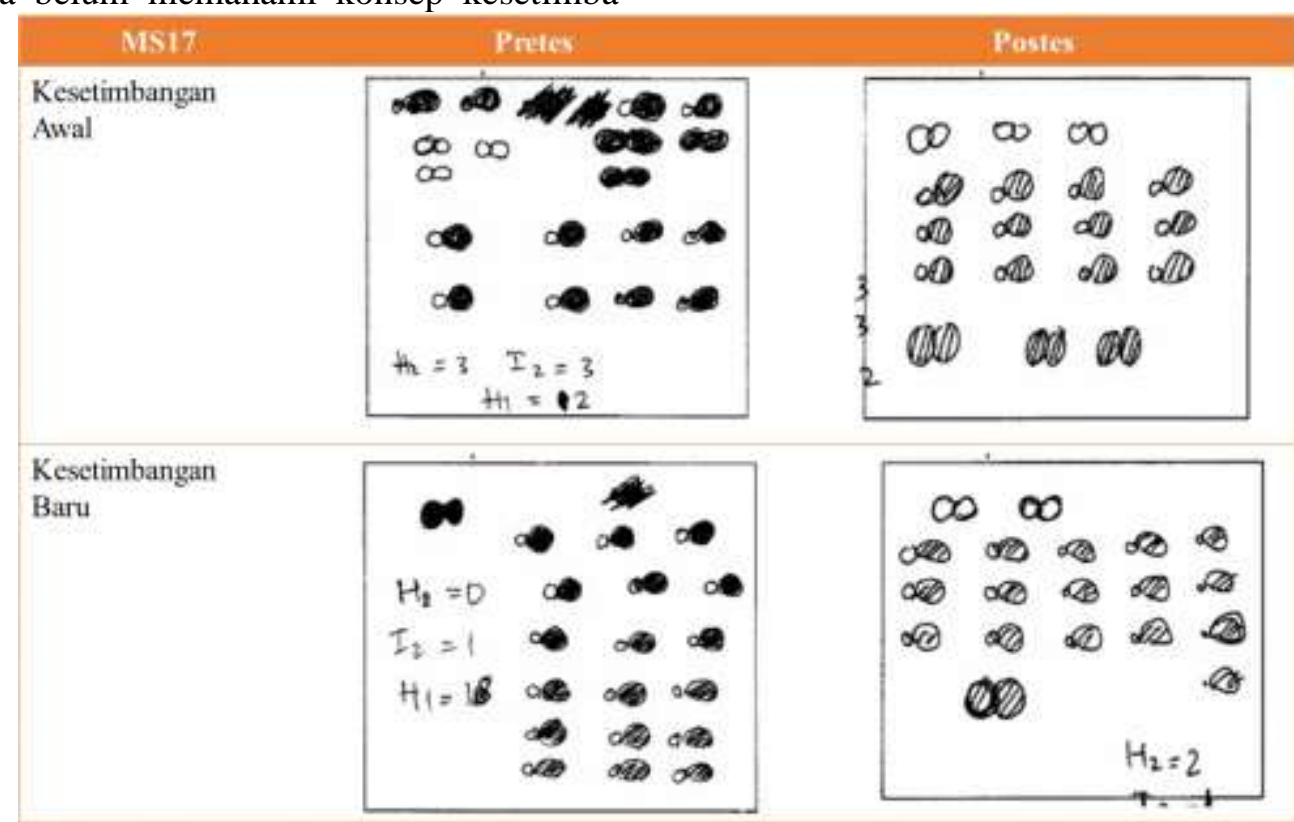

Gambar 3. Representasi Sub-Mikroskopis MS17 pada Kesetimbangan Awal dan Kesetimbangan Baru pada Pretes dan Postes

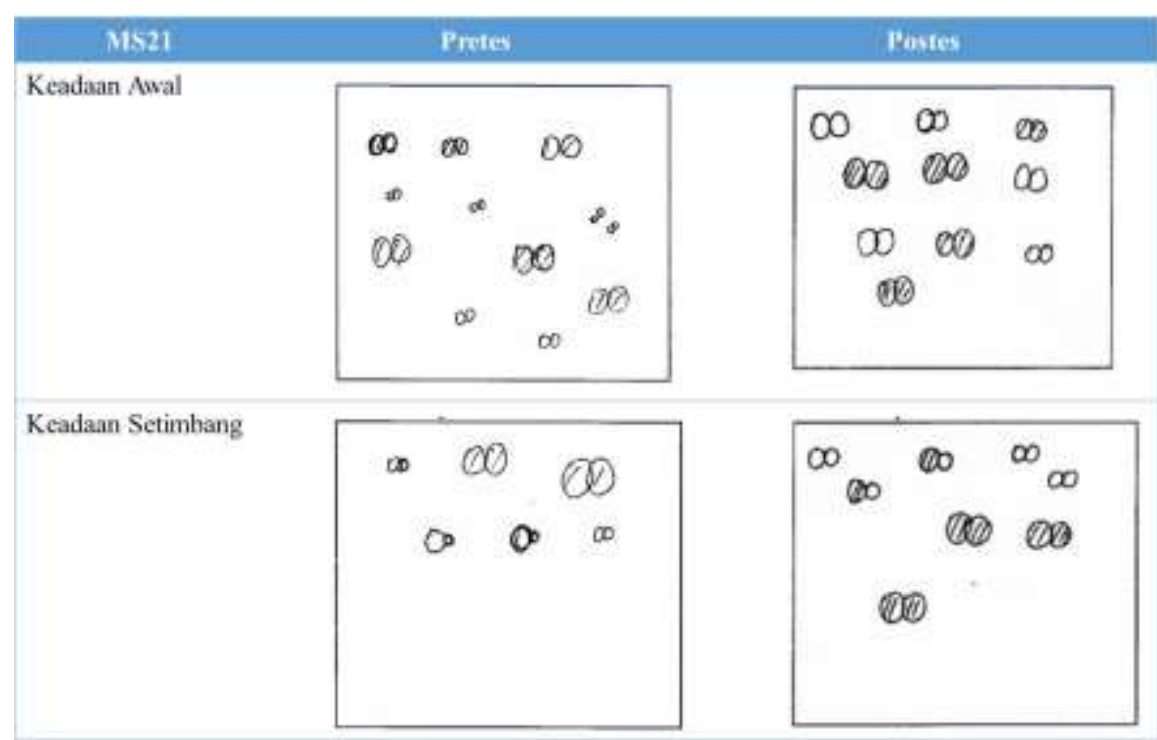

Gambar 4. Representasi Sub-Mikroskopis MS21 pada Keadaan Awal dan Setimbang pada Pretes dan Postes 


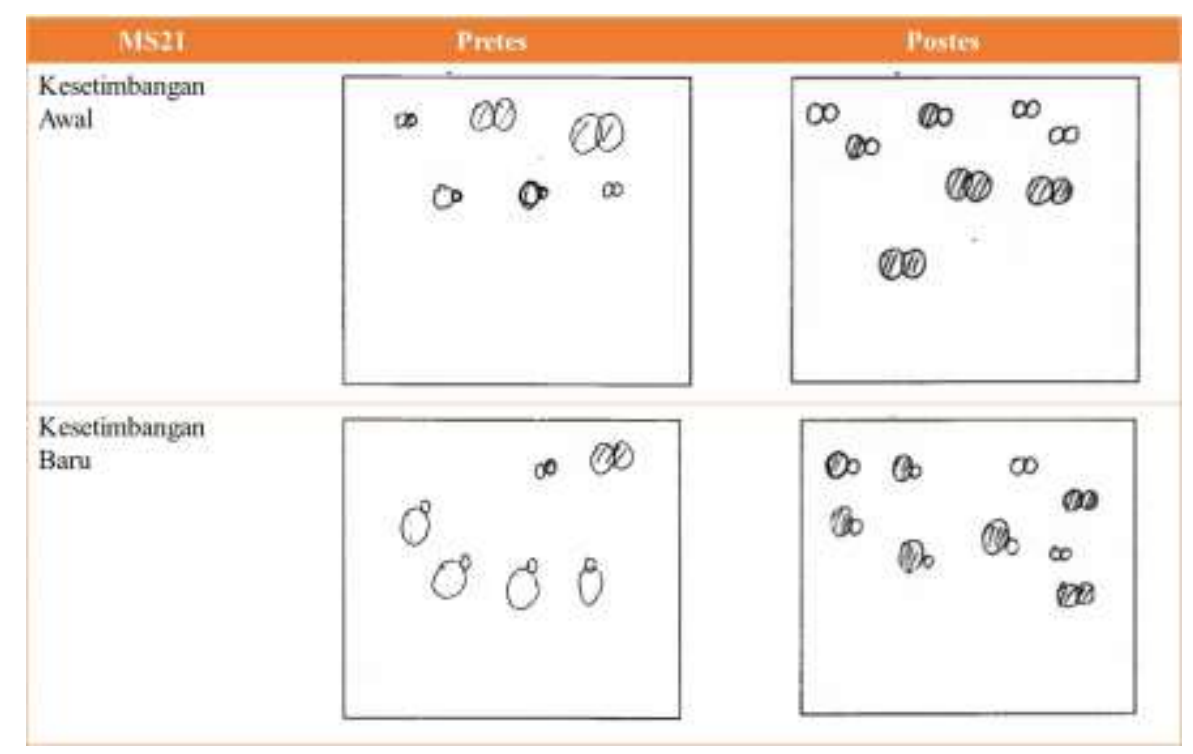

Gambar 5. Representasi Sub-Mikroskopis MS21 pada Kesetimbangan Awal dan Kesetimbangan Baru pada Pretes dan Postes

Sementara itu MS21 pada saat pretes menganggap bahwa jumlah zat yang terlibat dalam reaksi saat mencapai kesetimbangan sama. Hal ini terlihat dari jumlah $\mathrm{H}_{2}, \mathrm{I}_{2}$, dan $\mathrm{HI}$ yang sama pada representasi submikroskopis yang dibuat oleh MS21 pada Gambar 4. Pada saat postes terjadi perubahan representasi sub mikroskopisnya terhadap keadaan setimbang. Pada Gambar 4, terlihat bahwa, secara stoikiometri MS21 sudah benar dalam menentukan jumlah reaktan yang berkurang, namun masih salah dalam menentukan jumlah produk yang dihasilkan. Pada pembentukan kesetimbangan baru, saat pretes mahasiswa ini menganggap bahwa $\mathrm{H}_{2}$ bereaksi dengan $\mathrm{I}_{2}$ sehingga jumlah HI bertambah. Hal ini dapat dilihat pada Gambar 5. Namun, mahasiswa ini tidak memperhatikan jumlah $\mathrm{I}_{2}$ yang ditambahkan sehingga jumlah $\mathrm{H}_{2}$ dan $\mathrm{I}_{2}$ pada kesetimbangan baru tetap sama. Pada saat postes mahasiswa ini masih memiliki anggapan yang sama.

Stoikiometri reaksi kesetimbangan MS10 sudah benar baik saat pretes maupun saat postes. Hal ini dapat dilihat pada Gambar 6 . Namun, pada pretes saat kesetimbangan baru terbentuk, siswa ini menganggap bahwa jumlah $\mathrm{H}_{2}$ sudah tidak ada dan jumlah $\mathrm{I}_{2}$ lebih banyak karena adanya penambahan $\mathrm{I}_{2}$. Representasi sub- mikroskopis nya dapat dilihat pada Gambar 7 . Tetapi, pada postes mahasiswa ini telah mengerti dengan konsep kesetimbangan bahwa seluruh zat yang terlibat selalu ada dalam keadaan setimbang akan tetapi ia masih belum benar dalam membuat jumlah zat yang terlibat dalam reaksi tersebut.

Berdasarkan hal ini terlihat bahwa secara umum, model mental mahasiswa terhadap konsep kesetimbangan kimia berkem bang lebih baik setelah belajar menggunakan bahan ajar berbasis inkuiri terbimbing walaupun belum sepenuhnya membuat model mental mahasiswa sesuai dengan kebenaran ilmiah pada materi kesetimbangan kimia.

\section{KESIMPULAN}

Model mental mahasiswa terhadap konsep kesetimbangan kimia khususnya mengenai konsep keadaan setimbang dan tercapainya kembali keadaan setimbang setelah system diberikan aksi berkembang lebih baik setelah menggunakan bahan ajar berbasis inkuiri terbimbing walaupun belum sepenuhnya sesuai dengan kebenaran ilmiah pada konsep-konsep kesetimbangan. Hasil ini berimplikasi pada pembelajaran kimia khususnya pembelajaran kesetimbangan kimia dapat menggunakan bahan 
ajar ini untuk meningkatkan pemahaman siswa terhadap konsep-konsep pada materi ini.

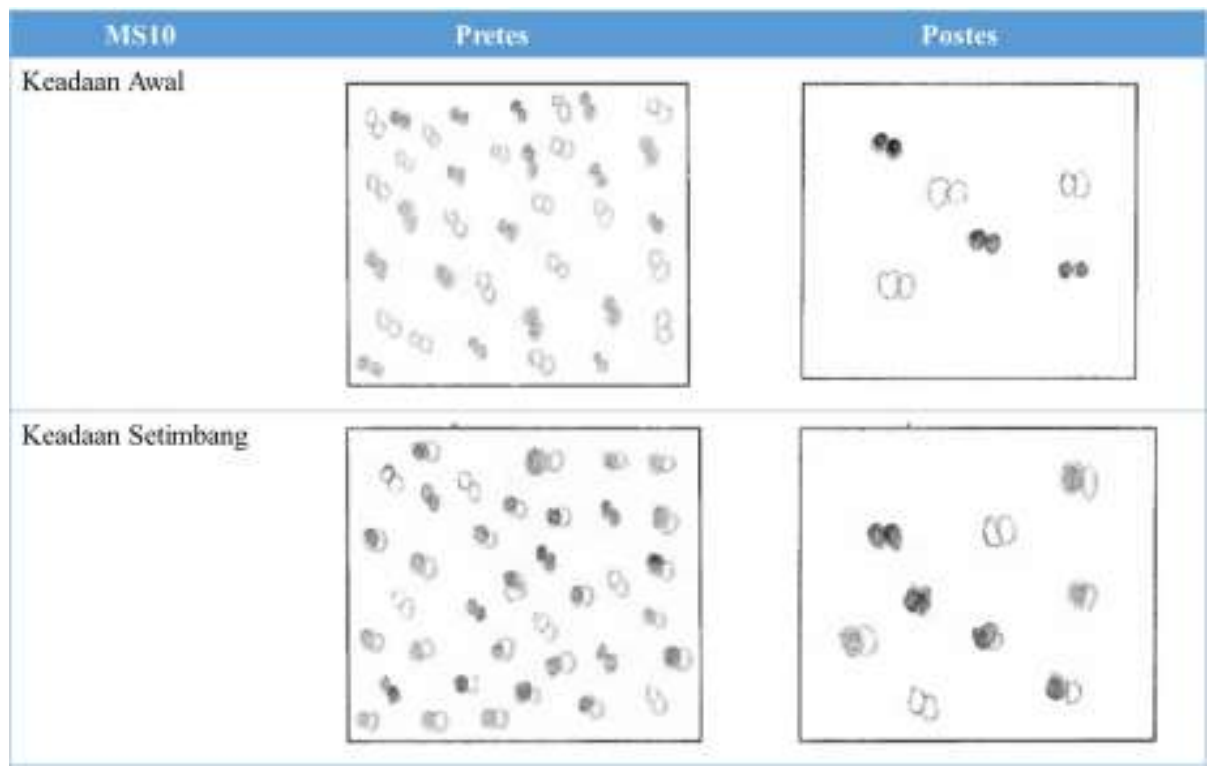

Gambar 6. Representasi Sub-Mikroskopis MS10 pada Keadaan Awal dan Setimbang pada Pretes dan Postes

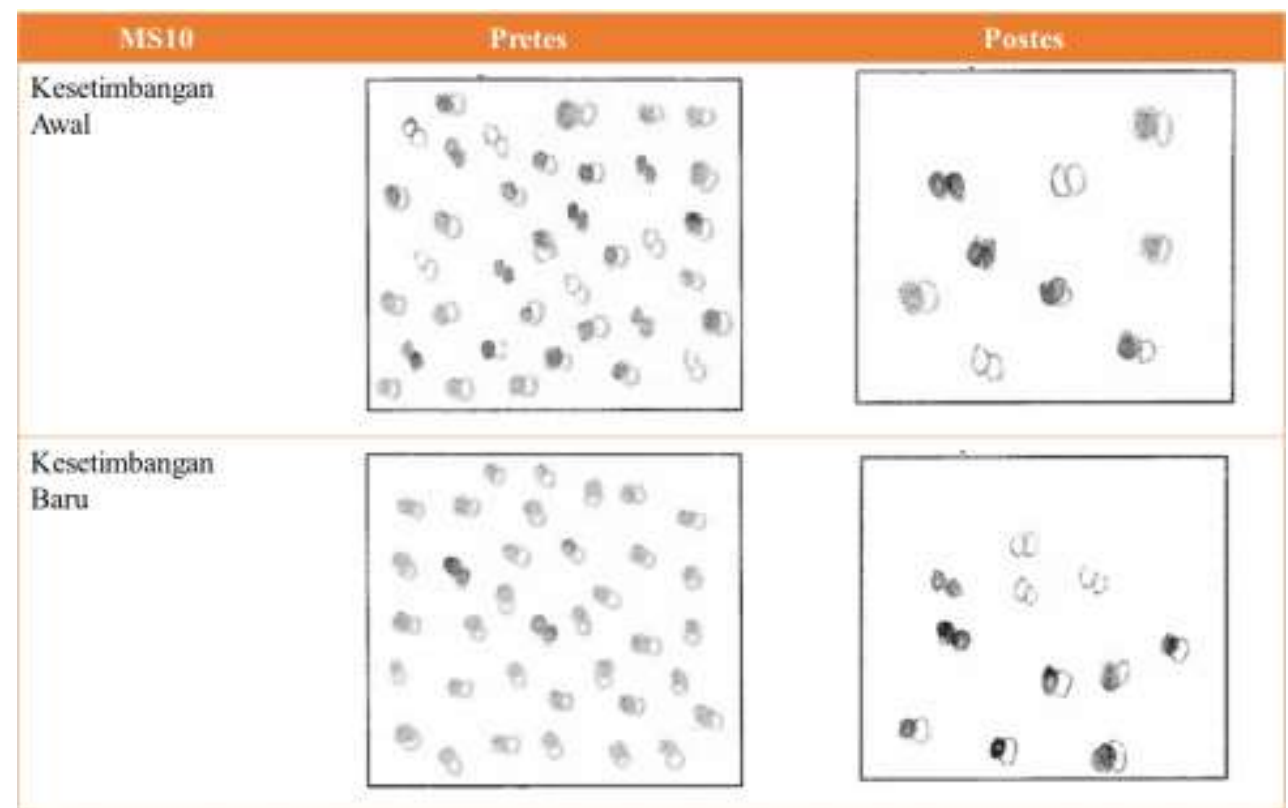

Gambar 7. Representasi Sub-Mikroskopis MS10 pada Kesetimbangan Awal dan Kesetimbangan Baru pada Pretes dan Postes

\section{DAFTAR PUSTAKA}

Aini, F. Q., Mawardi, M., \& Oktavia, B. (2017). Guided Inquiry Based Student Worksheet on Chemical Equilibrium Topic. Mauritius: LAP Lambert Academic Publishing.

Barke, H.-D., Hazari, A., \& Yitbarek, S. (2009). Misconceptions in Chemistry. Berlin:
Springer. https://doi.org/10.1007/978-3540-70989-3

Bergquist, W., \& Heikkinen, H. (1990). Student ideas regarding chemical equilibrium: What written test answers do not reveal. Journal of Chemical Education, 67(12), 1000-1003.

https://doi.org/10.1021/ed067p1000 
Chiu, M.-H., Chou, C.-C., \& Liu, C.-J. (2002). Dynamic processes of conceptual change: Analysis of constructing mental models of chemical equilibrium. Journal of Research in Science Teaching, 39(8), 688-712. https://doi.org/10.1002/tea.10041

Coll, R. K., \& Taylor, N. (2002). Mental Models In Chemistry: Senior Chemistry Students' Mental Models Of Chemical Bonding. CHEMISTRY EDUCATION: RESEARCH AND PRACTICE IN EUROPE, 3(2), 175184.

Cullen, D. M., \& Pentecost, T. C. (2011). A model approach to the electrochemical cell: An inquiry activity. Journal of Chemical Education, 88(11), 1562-1564. https://doi.org/10.1021/ed101146u

Hanson, D. M. (2013). Instructor's Guide to Process Oriented Guided Inquiry Learning. Hampton, New York: Pacific Crest.

Hunnicutt, S. S., Grushow, A., \& Whitnell, R. (2015). Guided-Inquiry Experiments for Physical Chemistry: The POGIL-PCL Model. Journal of Chemical Education, 92(2), 262-268. https://doi.org/10.1021/ed5003916

Ibrahim, B., \& Rebello, N. S. (2013). Role of mental representations in problem solving : Students ' approaches to nondirected tasks, 020106(July), 1-17. https://doi.org/10.1103/PhysRevSTPER.9. 020106

Johnstone, A. H. (1993). The Development of Chemistry Teaching A Changing Response to Changing Demand. Journal of Chemical Education, 70(9), 701-705.

Karpudewan, M., Treagust, D. F., Mocerino, M., Won, M., \& Chandrasegaran, A. L. (2015). Investigating High School Students, Understanding of Chemical Equilibrium Concepts. International Journal of Environmental \& Science Education, 10(6), 845-863. https://doi.org/10.12973/ijese.2015.280a

Kousathana, M., \& Tsaparlis, G. (2002). Students ' Errors In Solvig Numerical Chemical-Equilibrium Problems. Chemistry Education Research and
Practice In Europe, 3(1), 5-17. Retrieved from http://dx.doi.org/10.1039/B0RP90030C

Kuhlthau, C. C., Maniotes, L. K., \& Caspari, A. K. (2007). Guided Inquiry Learning in 21st Century. USA: Libraries Unlimited.

Ollino, M., Aldoney, J., Domınguez, A. M., \& Merino, C. (2018). Research and Practice A Coll anew multimedia application for teaching and learning chemical equilibrium. Chemistry Education Research and Practice, 19, 364-374. https://doi.org/10.1039/C7RP00113D

Özmen, H. (2007). The Effectiveness of Conceptual Change Texts in Remediating High School Students , Alternative Conceptions Concerning Chemical Equilibrium. Asia Pacific Education Review, 8(3), 413-425. Retrieved from http://doi.wiley.com/10.1002/tea.10041

Pedrosa, M. A., \& Dias, M. H. (2000). Chemistry Textbook Approaches To Chemical Equilibrium And Student Alternative Conceptions. Chemistry Education Research and Practice In Europe, 1(2), 227-236.

Supasorn, S., \& Promarak, V. (2015). Implementation of 5E inquiry incorporated with analogy learning approach to enhance conceptual understanding of chemical reaction rate for grade 11 students. Chemistry Education Research and Practice, 16, 121-132. https://doi.org/10.1039/C4RP00190G

The College Board. (2012). AP® Chemistry Guided-Inquiry Experiments: Applying the Science Practices (Teacher Manual). New York: The College Board.

The College Board. (2013). AP ® Chemistry Guided Inquiry Activities for the Classroom. New York: The College Board.

Tumay, H. (2014). Prospective chemistry teachers' mental models of vapor pressure. Chemistry Education Research and Practice, 15, 366-379. https://doi.org/ 10.1039/c4rp00024b 